
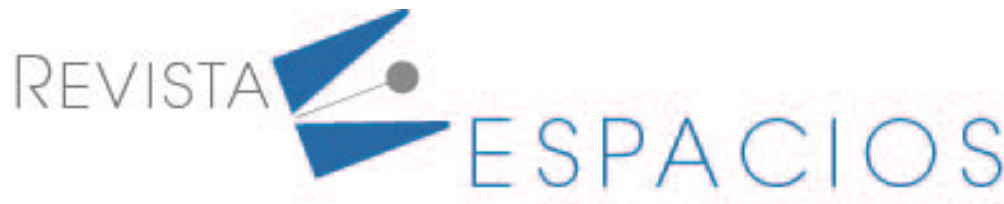

Educación • Education • Educação • Vol. 42 (15) 2021 • Art. 1

\title{
Synthesis of component and process of the development of functional competencies of heads of Department of Secondary Schools under Office of the Basic Education Commission, Thailand
}

\section{Síntesis del componente y proceso del desarrollo de competencias funcionales de los jefes de departamento de escuelas secundarias de la Oficina de la Comisión de Educación Básica, Tailandia}

\author{
AEBSAPAP, Teerasak ${ }^{1}$ \\ PARIYAPORN, Tungkunanan ${ }^{2}$ \\ BOONCHAN, Sisan ${ }^{3}$
}

\begin{abstract}
This research project had the objective of synthesizing and process of the development of functional competencies of Heads of Departments of secondary schools under Office of the Basic Education Commission in Thailand. The study of the synthesis of Heads of Departments is carried out in 3 steps, namely, 1) data reduction, 2) data display, and 3) conclusion drawing / verification. The findings were as follows. The 7 components consist of 1) intellectual leadership, 2) quality management, 3) educational innovation and information technology, 4) professionalism development, 5) curriculum, measurement and evaluation of learning, 6) learning organization, and 7) professional ethic. Key words: head of department, functional competencies, process of the development, synthesis of component
\end{abstract}

\begin{abstract}
Resumen
Este proyecto de investigación tuvo como objetivo sintetizar y procesar el desarrollo de las competencias funcionales de los Jefes de Departamentos de las escuelas secundarias dependientes de la Oficina de la Comisión de Educación Básica en Tailandia. El estudio de la síntesis de los Jefes de Departamento se realizó en 3 pasos: 1) reducción de datos, 2) visualización de datos y 3) elaboración / verificación de conclusiones. Los hallazgos fueron los siguientes. Los 7 componentes consisten en 1) liderazgo intelectual, 2) gestión de la calidad, 3) innovación educativa y tecnología de la información, 4) desarrollo del profesionalismo, 5) plan de estudios, medición y evaluación del aprendizaje, 6) organización del aprendizaje y 7) ética profesional.

Palabras clave: jefe de departamento, competencias funcionales, proceso de desarrollo, síntesis de componente
\end{abstract}

\footnotetext{
${ }^{1}$ Educational Administration. Faculty of Industrial Education and Technology. King Mongkut's Institute of Technology Ladkrabang. bellteerasak8088@gmail.com

${ }^{2}$ Educational Administration. Faculty of Industrial Education and Technology. King Mongkut's Institute of Technology Ladkrabang. pariyaporn.tu@kmitl.ac.th

${ }^{3}$ Educational Administration. Faculty of Industrial Education and Technology. King Mongkut's Institute of Technology Ladkrabang. kiboonch@kmitl.ac.th
} 


\section{Introduction}

The Sustainable Development Goals (SDGs) that the global society has agreed to be regarded as the framework and the goal for the development of the millennium, will guarantee, through Goal 4, that everyone will have right to quality education in the equal manner and is supported and encouraged to have lifelong learning (United Nations Organization in Thailand, 2015). All the boys and girls will have to finish the education in primary and secondary school levels that have quality in the equal fashion until the learning effectiveness is achieved in 2030. Everyone can access education in all levels, namely, vocational, graduate and post-graduate levels. Number of teachers with quality increases, and operations are executed through the international collaboration in training teachers in developing countries (United Nations Organization in Thailand, 2015). An important factor that will ensure the quality and efficiency of learning organization is teacher. Teachers can efficiently organize learning when they have knowledge and capabilities relating to their teaching professionalism. It can also be said that teachers must have competencies in order that it can be guaranteed that student will receive quality education (Weerawat, 2013). As a result, teachers have to continuously improve themselves in order to enhance their competencies and efficiency. Hence, professional teachers must have extensive knowledge of academic contents and learning organization methods that correspond to the sociology-technological changes in order to enhance the quality of the students to the extent where students can compete in the world. Consequently, teachers need more enhanced knowledge and expertise and have to improve their capabilities endlessly (Siriporn, 2015).

The performance of a teacher is a profession that requires expertise, skills or competencies that meet quality standards, or certain norms, learnt or attained from certain professional education courses (Siti, \& Herwin, 2020). Teachers have to consistently improve their quality by means of sufficient facilities and infrastructures for improving the quality of the learning process and outcomes (Sekar, Suminto, \& Siti, 2021). A responsibility of teachers is to ensure student achievement. A teacher should play an important role in developing himself/herself to meet educational needs of students. Hence, professional development must be in line with teachers' strengths and weaknesses to promote leadership, strengthen their competencies, and eliminate pedagogical practice that lacks of quality, in order to achieve the ultimate goal of student achievement, which in turn, develops a quality education system that concurs with the changes at that time (Mohd, Yahya, Ibrahim, \& Mat, 2020).

Head of Department is a position to be assumed by a teacher of that subject department, although some Heads of Departments lack of real experiences or competencies suitable for the position (Siriporn, 2015).

The objective of this work was to study on the way to develop functional competencies of Heads of Departments of secondary schools. The findings from this study can be implemented to the design of the model of the development of functional competencies of Heads of Departments of secondary schools under Office of the Basic Education Commission in Thailand. School administrators can apply the findings from the study to real situations, in order to enable Heads of Departments to have quality operations that turn the academic institutes the learning centers with quality and sustainability.

\section{Methodology}

\section{Synthesis of the components of functional competencies of heads of department}

\section{Step 1: Data compilation and reduction}

Studies containing competencies of Heads of Departments were examined with the process of selecting, focusing, simplifying, abstracting and transforming the data into a specific group of the same genre or type of the functions. The sources for gathering the data are vital as they must be reliable; in this sense, there was only examined the data from the databases of Journal of Educational Administration; School Leadership \& Management; Education as Change; Leadership and Policy in Schools; International Journal of Educational Sciences; Burapha 
University; Srinakharinwirot University; Chulalongkorn University; King Mongkut's University of Technology North Bangkok; Phranakhon Rajabhat University; Academic Journal of Eastern Asia University; Office of the Basic Education Commission; Praewa Kalasin Academic Journal Kalasin University, and Krupibul Journal.

\section{Step 2: Data display}

This step was to display the synthesized information gathered in the first stage in a well-organized and compressed form. The data were shown in form of the concise groups of meaning representing strong relationship and connection within the groups. The reliable sources for synthesizing this work was shown in Table 1 including the studies and official papers of Angela, (2010)., Brown, Boyle, \& Boyle, (2002)., Clive, Raj, \& Alfred, (2013)., Kenneth, (2016)., Teresa, (2017)., Rawiwan, (2005)., Namchai, (2007)., Somnuek, (2007)., Naphason, (2010)., Jaruphat, (2013)., Phat, \& Direk, (2013). Office of the Basic Education Commission,(2013). Phinit, (2017), and Nannaphat, (2018).

\section{Step 3: Conclusion, interpretation and verification}

The third stream of analysis activity was to draw the conclusion and verify the data again. At this stage, the data entries which were clarified, coded and categorized by analyzing their regularities, patterns, explanations, possible configurations, causal flows, and propositions were reexamined in order to ensure the correct groups of each category and to avoid repetitiveness. Then the verification process was done in order to gain the overall accuracy and trustworthiness.

\section{Process of the development of functional competencies of heads of departments}

Step 1: I, the researcher, have studied on approaches, principles, theories and research works relating to the processes of the development of functional competencies of Heads of Departments, and then synthesize the learnt data in order to identify the steps in the process of the development of functional competencies of Heads of Department of secondary schools under the Office of the Basic Education Commission. I have set the criteria for selecting the steps that each of the synthesized step must have frequency that is not inferior to 3 , so that it is defined as a step in the process of the development of functional competencies of Heads of Departments. At the same time, the steps with frequencies lower than 3 may be included in the process as deemed appropriate.

Step 2: The creation of a process of the development of functional competencies of Heads of Departments of secondary schools under the Office of the Basic Education Commission in Thailand is based on the interviews with experts. The key informants are 15 experts of functional competencies of Heads of Departments, who are 2 lecturers from the Faculty of Education that has the course of educational administration, in higher education institutions; 2 lecturers from the Faculty of Education that has the course of curriculum and teaching, in higher education institutions; 2 people directors of educational areas; 3 directors of secondary schools; 3 deputy directors of education institutes in academic management group, secondary schools; and 3 Heads of Department of secondary schools. The data was analyzed with content analysis technique to find common characteristics and common conclusion, which can be implemented to the formulation of a research concept, or concept of the process of the development of functional competencies of Heads of Department of secondary schools under the Office of the Basic Education Commission and guidelines for developing the competencies, by each component.

\section{Results}

\section{Synthesis of the components of Functional Competencies of Heads of Department}

The reliable sources for synthesizing this work was shown in Table 1. 
Table 1

Components of heads of department's

functional competencies

\begin{tabular}{|c|c|}
\hline Components & Sources \\
\hline $\begin{array}{l}\text { Decision making, Utilization of special competencies of each } \\
\text { teacher to the full capacity, Creation of vision, Empowerment for } \\
\text { teachers, Change in beliefs and enhancement of capabilities } \\
\text { ofcColleagues, Becoming learning leader, Motivation for } \\
\text { colleagues, Creation of the atmosphere for working together, } \\
\text { Leadership for change, and Creativity }\end{array}$ & $\begin{array}{l}\text { Angela, (2010)., Brown, Boyle, \& Boyle,(2002)., } \\
\text { Clive, Raj, \& Alfred, (2013)., Kenneth, (2016)., } \\
\text { Teresa, (2017)., Rawiwan, (2005)., Namchai, } \\
\text { (2007)., Somnuek, (2007)., Jaruphat, (2013)., and } \\
\text { Phat, \& Direk, (2013). }\end{array}$ \\
\hline $\begin{array}{l}\text { Making of strategic plan, Planning and management, Making of } \\
\text { academic plan and development of internal quality assurance } \\
\text { system, and Educational standard }\end{array}$ & $\begin{array}{l}\text { Angela, (2010)., Brown, Boyle, \& Boyle, (2002), } \\
\text { Naphason, (2010)., Jaruphat, (2013)., and } \\
\text { Nannaphat, (2018). }\end{array}$ \\
\hline $\begin{array}{l}\text { Exchange of work-related knowledge among teachers for } \\
\text { teaching innovations, Research for learning development, } \\
\text { Capability of designing of innovative media and technologies } \\
\text { suitable for contents, Activities and learners and development, } \\
\text { and utilization of media, and Technologies for education }\end{array}$ & $\begin{array}{l}\text { Brown, Boyle, \& Boyle, (2002)., Kenneth, (2016)., } \\
\text { Teresa, (2017)., Rawiwan, (2005)., Namchai, } \\
\text { (2007)., Somnuek, (2007)., Naphason, (2010)., } \\
\text { Jaruphat, (2013)., and Phinit, (2017). }\end{array}$ \\
\hline $\begin{array}{l}\text { Consistent self-development, Work experience, Learning pursuit } \\
\text { and building of network for professionalism development }\end{array}$ & $\begin{array}{l}\text { Kenneth, (2016), Office of the Basic Education } \\
\text { Commission. (2013)., and Phinit, (2017). }\end{array}$ \\
\hline $\begin{array}{l}\text { Curriculum development, Supervision, Capability of making } \\
\text { curriculum for educational institute, Capability of consultation } \\
\text { and development for teachers to develop curricula, and Make } \\
\text { assessment and evaluation, Development or execution relating } \\
\text { to contents of curricula, and Process of learning development }\end{array}$ & $\begin{array}{l}\text { Clive, Raj, \& Alfred, (2013)., Kenneth, (2016)., } \\
\text { Rawiwan, (2005)., Somnuek, (2007)., Naphason, } \\
\text { (2010)., Phat, \& Direk, (2013)., Phinit, (2017), and } \\
\text { Nannaphat, (2018). }\end{array}$ \\
\hline $\begin{array}{l}\text { Learning organization, Capability of learner-oriented learning } \\
\text { organization with diversified methods, and Learning organization } \\
\text { in educational institutes }\end{array}$ & $\begin{array}{l}\text { Somnuek, (2007)., Phat, \& Direk, (2013)., Office of } \\
\text { the Basic Education Commission. (2013)., and } \\
\text { Nannaphat, (2018). }\end{array}$ \\
\hline $\begin{array}{l}\text { Participation, Promotion of status of colleague among teachers, } \\
\text { Responsibility, Trust, Good communication, Attachment to } \\
\text { organization, Justice, Service mind, Teamwork, Ethicality, and } \\
\text { Good service }\end{array}$ & $\begin{array}{l}\text { Angela, (2010)., Kenneth, (2016)., Teresa, (2017)., } \\
\text { Rawiwan, (2005)., Naphason, (2010)., and Jaruphat, } \\
\text { (2013). }\end{array}$ \\
\hline
\end{tabular}

The 7 groups of components of functional competencies of Heads of Department of secondary schools under the Office of the Basic Education Commission were grouped as 1) intellectual leadership; 2) quality management; $3)$ innovation and information technology for education; 4) professionalism management; 5) curriculum, measurement and evaluation; 6) learning organization; and 7) professional ethic.

\section{Process of the Development of Functional Competencies of Heads of Departments}

Step 1: The process of the development of functional competencies of Heads of Department of secondary schools under Office of the Basic Education Commission from different sources of knowledge is analyzed in Table 2. 
Table 2

Analysis of concepts of the development of the process of the development of functional competencies of heads of departments of secondary schools under the office of the basic education commission

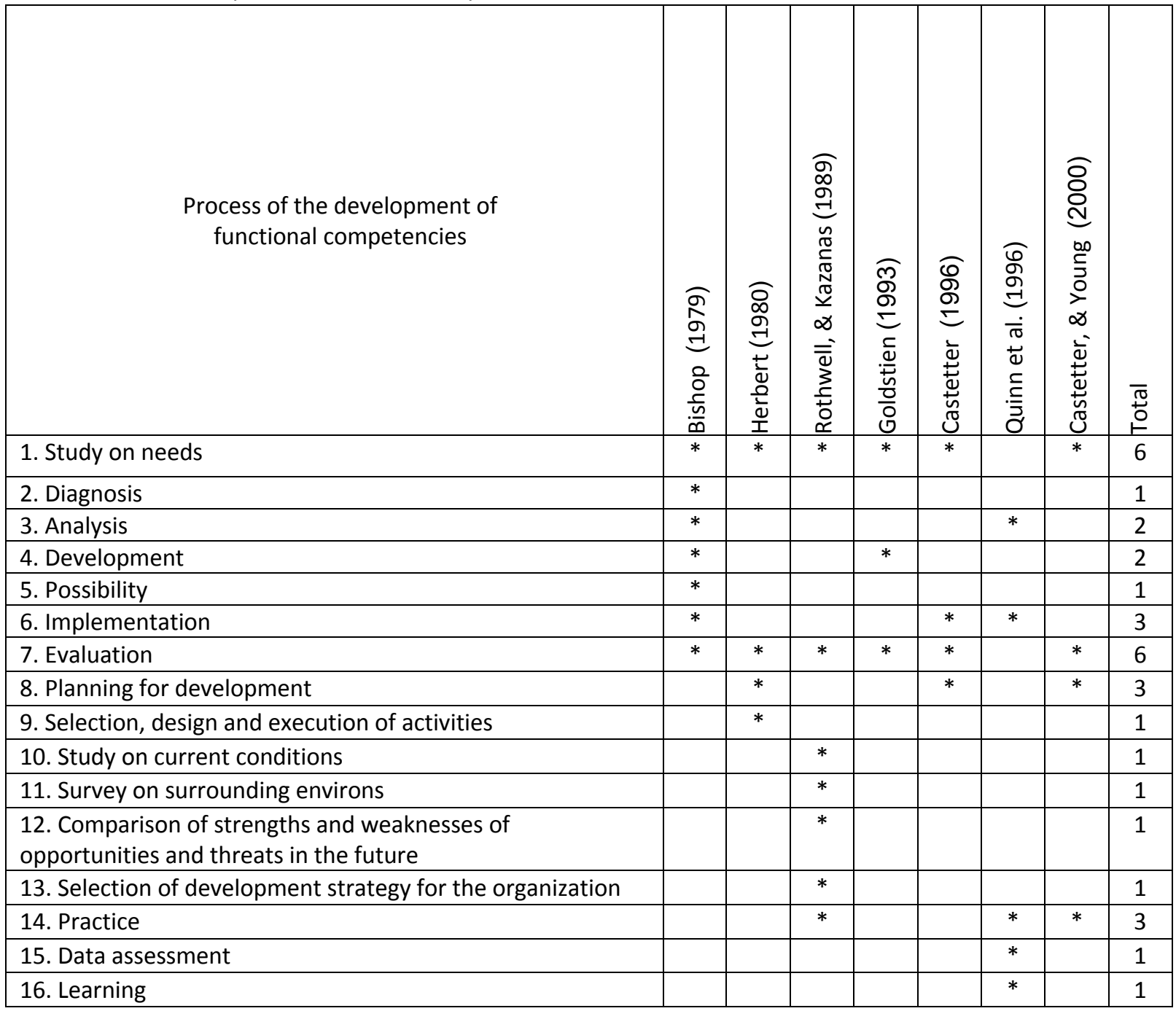

From the analysis in the Table above, steps in the process of the development of functional competencies of Heads of Department of secondary schools under the Office of the Basic Education Commission in Thailand can be synthesized. The criterion for each step to be chosen to be included in the process of the development of functional competencies of Heads of Departments is the frequency of not less than 3. At the same time, each of steps that have a frequency that is less than 3, may be selected as deemed appropriate. From Table 2 and the specified criterion, there are 5 steps for the development of functional competencies of Heads of Department of secondary schools under the Office of the Basic Education Commission as follows: 1) Study on needs, 2) Planning for development, 3) Practice, 4) Implementation and 5) Evaluation. The selection of any other step was not deemed appropriate.

Step 2: Findings from the interviews with 15 educational experts who have knowledge and experiences in developing functional competencies of Heads of Department or have knowledge and experiences in performing duties of the Heads of Department in order to identify the way to develop functional competencies of Heads of Department of secondary schools under the Office of the Basic Education Commission in Thailand as follows. The agenda for the Interviews regarding the way to develop functional competencies of Heads of Department of secondary schools under the Office of the Basic Education Commission in Thailand are Study on needs, Planning 
for development, Practice, implementation and evaluation for the development of functional competencies of Heads of Departments of secondary schools under the Office of the Basic Education Commission in Thailand. The researcher has included it in the selected step as appropriate. Create research tools to create a semi-structured interview form. by interviewing qualified. The researcher analyzed the data by analyzing the content to find common characteristics and find a common conclusion to formulate research concepts. Concepts on the process of developing competency in the line of work of the head of the learning subject group at the secondary school level.

\section{Functional competencies}

The creation of a process of the development of functional competencies of Heads of Department of secondary schools under the Office of the Basic Education Commission in Thailand is based on the interviews with experts. The key informants are 15 experts of functional competencies of Heads of Departments. The researcher has included it in the selected step as appropriate. Create research tools to create a semi-structured interview form by interviewing qualified. The researcher analyzed the data by analyzing the content to find common characteristics and find a common conclusion to formulate research concepts. Concepts on the process of developing competency in the line of work of the head of the learning subject group at the secondary school level.

\section{1: Study on needs}

The Study on needs for functional competencies of Heads of Departments of secondary schools focuses on basic information, knowledge, experiences, skills and attitudes, which can be done in different ways, such as to identify strengths and weaknesses, to do research from the Head of Department's self-improvement plan, or to use questionnaire survey, test and interviews on the needs for functional competencies, namely, intellectual leadership, quality management, innovation and information technology for education, professionalism development, curriculum/ measurement and evaluation, learning organization and professional ethic. There may be competency assessment on each of the Heads of Department, or the appointment of expert committee to identify functional competencies.

\section{2: Planning for development}

To educate Heads of Departments of functional competencies should be based on the findings from the Study on Needs. The known competencies and awareness are analyzed to classify problems or to identify competencies that should be addressed and competencies that should be enhanced, with methods for providing knowledge determined, such as having the Heads of Department have self-improvement by attending the training before applying the knowledge attained from the training to the improvement of the performances for diversity and attractiveness, to educate Heads of Department so that the Heads of Department can review their own knowledge and abilities, to organize knowledge exchange activities among Heads of Department, to invite experts to give lectures, to have the, participate in professional learning community, to arrange academic seminars, to form a network of Heads of Department, to organize a focus group for all Heads of Departments that are performing duties to share experiences and problems encountered in practice to exchange with one another so that others can propose solutions to the development of functional competencies, and to plan for the development of functional competencies of each individual Head of Department so that each Head of Department can improve functional competencies as planned, and learn about different methods from other Heads of Department and experts which can be applied, and to pay education visits to agencies that prototypes for the development of functional competencies of Heads of Departments. Furthermore, Heads of Department should be encouraged to do research works on the management of each subject department to develop their efficiency and performances. 


\section{3: Practice}

The practice for the development of functional competencies of Heads of Department may be carried out through the designing of scenarios in which different problems are added to the normal operation of the Head of Department, starting from planning for the work systematically or planing for routine work, evaluating the performance periodically with clear goals, and practicing doing research works in the classroom. Such practice helps teachers think creatively in order to find appropriate solutions to problems. Practice should be supervised in different fashions, of there should be the activities of Head of Department exchange from different the school campuses to let Heads of Department earn experience and learn from diversified students and fellow teachers.

\section{4: Implementation}

After the practice, teachers must apply their knowledge and techniques and know-how to the analysis, synthesis and operations by creating or improving self-development plans with diversified functions, such as active learning, which are suitable for each level of competencies. Knowledge obtained from practice is applied to the improvement of performances, with the focus on students, and to daily life until essential skills and competencies are developed. In addition, Heads of Department should implement knowledge, skills and problem solving processes learnt from the scenarios to the real situations faced by the subject departments, with diversified monitoring methods set.

\section{5: Evaluation}

After the practice and the implementation steps to the development of functional competencies of Head of Department, the evaluation of the Head of Department's performance includes the self-assessment by the Head of Department, and the assessments by students, administrators, teachers in the same department, parents and third parties involved. Development may be periodically assessed. Also, experts may be asked to observe the performance and provide feedback on the good performances and poor performances to be improved that should be made in order to improve the performance to the teachers. Finally and importantly, there should be the evaluation of students well as providing the enhancement of the morale of the Head of Department who has shown good performances in order to encourage other Heads of Department who have not received practical training to improve their competencies.

\section{Discussion}

The data were synthesized to determine the components of functional competencies of Heads of Department of secondary schools under Office of the Basic Education Commission, Thailand; the following 7 components were discovered:1) intellectual leadership; 2) quality management; 3) innovation and information technology for education; 4) professionalism management; 5) curriculum, measurement and evaluation; 6) learning organization; and 7) professional ethic.

The findings from the study on the way to develop functional competencies of Heads of Department of secondary schools under the Office of the Basic Education Commission in Thailand can be concluded, based on the five steps of the development, as follows. All the interviewed experts have ideas that are concurrent with those of one another's that the way to develop functional competencies of Heads of Department of secondary schools under the Office of the Basic Education Commission in Thailand that consists of 5 steps that are suitable and applicable to the creation of mechanism for the development of functional competencies of Heads of Department of secondary schools under the Office of the Basic Education Commission in Thailand. The significant idea is that the way of such development should be cyclical after each teacher has completed the five steps in order to get the outcomes from the development in the comparative manner. From the findings from the research, the way to develop functional competencies of Heads of Departments of secondary schools under the Office of the Basic Education Commission in Thailand consists of the following steps. 
Step 1 is the study on needs which is the study on fundamental information, knowledge, experiences, skills and attitudes, which include 1) the identification of functional competencies of Heads of Departments of secondary schools under Office of the Basic Education Commission in Thailand, and 2) the evaluation of the awareness and functional competencies of Heads of Departments of secondary schools under Office of the Basic Education Commission in Thailand. Step 2 is the planning for the development which is to provide knowledge of functional competencies to Heads of Department, which is the analysis of the outcomes from the identification of competencies and awareness in Step 1, in order to classify problems. and competencies that need solutions and competencies need be promoted and developed, together with the determination of knowledge dissemination methods. Step 3 is the practice in order to develop competencies through scenarios in which problems of different kinds are simulated to interfere the course of normal operation of a Head of Department. Step 4 is the implementation of bodies of knowledge, techniques and methods which are analyzed, synthesized and applied to the actual works by making or improving the plan for learning organization, having self-development activities, making learning organization plan and developing learning activity organizations, in diversified patterns. Step 5 is the evaluation that includes the Head of Department's self-assessment and assessments by students, administrators, teachers in the same department, parents and third parties involved. The evaluation of the development is periodic, with experts who observe the operation giving feedback on good things and poor things that need improvements. Vitaly et al. (2017) have explained that the conducted study revealed a significant influence on the motivation of heads of resuscitation departments of a hospital to improve the skills of such factors as gender, work experience, financial interest, duty considerations, and career interest. The causes for the untimely advanced training have been revealed for five years, among which the constricting role of the management, family problems, high self-esteem of one's qualifications. According to the doctors, the best forms and duration of the advanced training are thematic and short-term. The need for the advanced training on management issues has been particularly highlighted. Erke et al. (2019) have explained that the success of the professional activity of the head of pre-school educational organization depends on a certain set of individual psychological characteristics, professional and business qualities of his personality. Professionally important qualities of the Manager's personality are personal characteristics providing maximum efficiency and success of the head in the sphere of administrative activity. The purpose of the article is to reveal the connection between the style management of the head of a pre-school educational organization and his/her leadership skills. Siriporn, (2015) have explained that the purposes of the research were to study the factors and indicators of characteristics that facilitate the participative management of department heads in schools under Bangkok Metropolitan Administration and to check the concurrent validity of those indicators by the known groups. The research procedures were divided into 3 steps. Step 1 : Setting the factors and the indicators of characteristics that facilitate the participative management of department heads by analyzing and synthesizing the related literatures and interviewing experts. Step 2 : Developing indicators of characteristics that facilitate the participative management of department heads by using the questionnaire to collect data from 478 samples. The data were analyzed by using exploratory factor analysis, principal component analysis, and orthogonal varimax rotation. And step 3 : Testing the concurrent validity with 48 known-group experts. Data analysis was done by using One Sample t-test. The research results were as follows: 1 . There were 9 factors with 64 indicators of characteristics that facilitate the participative management of department heads in schools under Bangkok Metropolitan Administration. They were 1) Instructional leadership with 12 indicators, 2) Autonomy with 10 indicators, 3) Trust with 8 indicators, 4) commitment with 9 indicators, 5) Personality with 7 indicators, 6) Teamwork with 3 indicators, 7) Decision-Making with 6 indicators, 8) Goals and objectives setting with 6 indicators, and 9) Communication with 3 indicators. 2. Every indicator of characteristics that facilitates the participative management of department heads in schools under Bangkok Metropolitan Administration was approved as the concurrent validity one. 
From the study on the components of functional competencies of Heads of Department of secondary schools in Thailand, it can be concluded as follows. Educational institutions that can develop their Heads of Department to have functional competencies must pay attention to all the aforementioned components. In addition, the findings from this research have confirmed that components of functional competencies of Heads of Department of the secondary school level under the Office of the Basic Education Commission in Thailand, include Curriculum, Measurement and evaluation, Professionalism development, Intellectual leadership, Professional ethic, Learning organization and Quality management. These components are included in the model for functional competencies of the Heads of Department of secondary schools under the Office of the Basic Education Commission in Thailand, which has been developed on the bases of the findings from the study.

\section{Conclusions}

The way to develop functional competencies of Heads of Department of secondary schools under the Office of the Basic Education Commission in Thailand is to enhance the readiness for the operation of Heads of Department, and to create values in order to ensure that the education organization is cost-effective and has quality in accordance with the criterion for sustainably efficiency and effectiveness.

\section{Bibliographic references}

Angela, C. F. T. (2010). Understanding the leadership qualities of a head of department coping with curriculum changes in a Hong Kong secondary school. School Leadership \& Management. 30(4), 367-386.

Bishop, L.J. (1979). Staff development and instruction improvement: Plan and Procedure. Boston: Allyn and Bacon.

Brown, M., Boyle, B., \& Boyle, T. (2002). Professional development and management training needs for heads of department in UK secondary schools. Journal of Educational Administration. 40(1), 31-43.

Castetter, W.B. (1996). The human resource function in educational administration. $6^{\text {th }}$ ed. New Jersey: Prentice-Hall.

Castetter, W.B., \& Young, I.P. (2000). The human resource function in educational administration. $7^{\text {th }}$ ed. New Jersey: Prentice-Hall.

Clive, S., Raj, M., \& Alfred, B. (2013). Role-players' experiences and perceptions of heads of departments' instructional leadership role in secondary schools. Education as Change. 17(1), 163-176.

ERKE, V. I.; BUBNOVA, I. S.; TATARINOVA, L. V.; BERINSKAYA, I. V. \& BABITSKAYA, L. A. (2019). The leadership problem and style of managing the pedagogical staff of preschool educational organization. Espacios. 40(8), 30.

Herbert, G.H. (1980). Personnel/Human Resource Management. Illinois: Ricard D. Irwin.

Jaruphat, B. (2013). Development of teaching leadership indicators of the heads of Thai learning subject groups in secondary school under the Office of the Basic Education Commission Northeastern Region. Ph.D. Department of Leadership in Educational Administration. graduate school. Phranakhon Rajabhat University.

Kenneth, L. (2016). Department-Head Leadership for School Improvement. Leadership and Policy in Schools. 15(2), 117-140. 
Mohd, F. M. Y., Yahya, D., Ibrahim, S., \& Mat, R. Y. (2020). Teachers' Professional Development Level across Cohort of Generations in Malaysia. International Journal of Instruction. 13(4), 443-456.

Namchai, S. (2007). Study of the relationship of multilevel linear structures Leadership factor Factors of learning subject groups and personal factors affecting social exchange networks in the workplace and variables affecting psychology of subject group leaders and secondary school teachers in Bangkok. Ph.D. Applied Behavioral Science Research Program. Graduate School, Srinakharinwirot University.

Nannaphat, B. (2018). Development of a curriculum to enhance academic leadership for heads of learning subject groups in educational institutions under local government organizations. Krupibul Journal, 6(1), 134-150.

Naphason, S. (2010). Training model for department heads to develop a problem-based learning training course for teaching and learning management. Doctorate of Industrial Education Vocational Administration and Technical Education. Department of Technical Education Administration. graduate school. King Mongkut's University of Technology North Bangkok.

Office of the Basic Education Commission. (2013). School Management Manual in the Juristic Person Management Development Project. Bangkok: Agricultural Cooperative Association of Thailand.

Phat, S., \& Direk, P. (2013). Transformational Leadership Empowerment Model Academic Teacher Head of Department High School under the Office of the Basic Education Commission. Academic Journal of Eastern Asia University. 3(2), 57-70.

Phinit, N. (2017). Development of a competency training course for the subject group leader in secondary schools Under the Office of Secondary Education Service Area, Region 20. Praewa Kalasin Academic Journal Kalasin University. 4(3), 454-472.

Quinn et al. (1996). Becoming a master manager : A competency framework. New York: John Wiley and sons.

Rawiwan, P. (2005). Administrative competence of departmental level executives Nursing Science State University. Department of Educational Administration. Graduate School, Burapha University.

Rothwell, W.J. \& Kazanas. (1989). H.C. Strategic human resource development. New Jersey: Prentice Hall.

Sekar, P. K., Suminto, A. S. A. \& Siti, I. A. D. (2021). Teachers Quality and Educational Equality Achievements in Indonesia. International Journal of Instruction. 14(2), 811-830.

Siriporn, S. (2015). Developing character indicators that facilitate the participatory management of supervisors learning subject group in schools affiliated with Bangkok. Doctor of Education. Department of Educational Administration. Graduate School, Srinakarinwirot University.

Somnuek, T. (2007). Developing a model for developing administrative competency for middle-level executives in an autonomous university. Doctor of Education. Education Administration Department of Policy Educational Management and Leadership. Faculty of Education, Chulalongkorn University.

Teresa, A. O. (2017). How heads of Departments Understand Their Roles as Instructional Leaders: A South African Study. International Journal of Educational Sciences. 18(1), 224-230.

United Nations Organization in Thailand. (2015). Sustainable Development Goals (SDGs), Full Version. [Online]. Available http://e-plan.dla.go.th/activitylmage/422.pdf 
Vitaly, V. S. ; Alexander, K. B. ; Valentina, N. O. \& Egor, E. O. (2017). Features of Professional Needs of Resuscitation Department Heads in Upgrading the Level of Personal Competence and Postgraduate Education. Espacios. 38(40), 41.

Weerawat, D. (2013). Leadership development model for change of group leader learning in high school Under the Office of Secondary Education Service Area Districts 22 and 23. Doctor of Education. Department of Educational Administration. Graduate School, Ratchaphatsakonnakorn University.

\author{
Esta obra está bajo una Licencia Creative Commons \\ Attribución-NoCommercial 4.0 International \\ (cc) EY-NC
}

